\title{
Ewì Gẹ́gẹe Bí Ètè Ogun Jíjà Láwùjọ
}

\author{
Luqman Abísộlá Kíaríbèé \\ Ẹka-Ẹkọ́ İmọ Ẹdá-Ėdè Àti Èdè Adúláwọ̀ \\ Yunifásiti İpínlè Òș̣un, Nàiórín. \\ luqman.abisola@gmail.com tàbí luqman.abisola@yahoo.com
}

\begin{abstract}
Àșamò
Oríșiíríșií ète ni àwọn jagunjagun máa ń șàmúlò láyé àtijộ láti fi șẹgun ọ̀tá. Díẹ lára àwọn ète wọ̀nyí ni ìdẹ́rùbani, olè jíjà, agbára oògùn àti bíba irè oko àwọn ọ̀tá wọn jệ. Àwọn ișe ì ìádií ti wáyé lórísiiíríșií lórí ogun jíjà láwùjọ Yorùbá șùgbọ́n kò sí iṣé ìwádí kan gbòógì tó șe àgbéyệwò ewì gẹgẹe bí ète ogun jíjà ní pàtó, ní kíkún. Lọ́nà àti dí àlàfo yî́, ișẹ́ ìwádií yìi fi ojú ìmọ̀ìtàn-mọ́-lítíréṣọ șe àtẹgùn láti șe àgbéyẹ̀wò ewì gẹgẹe bí ète ìjagun ní àwùjọ Yorùbá. A mọo-ọnmọ̀ șàsàyàn àwọn ogun tí ó ti wáyé nínú ìtàn láwùjọ Yorùbá nínú èyí tí wọ́n ti șàmúlò ewì láti sẹegun ni. A fi ộọ̣ wá àwọn àgbà àti àwọn tó nímọ̀ nípa ogun lẹ́nu wò. Bákan náà ni a șe ìtúpalẹ àwọn ewì tí wọ́n lò, lộnà àti mọ ìdí tí ète náà fi mú ọ̀tá tí wộn dẹ ẹ̣ fún. Orin lóríșiîrișịi àti oríkì ni iṣẹ ìwádî́ șe àfihàn pé wộn lò gẹgẹe bí ète láti mú ọ̀tá nínú ogun tí a yẹ̀wò. Bákan náà ni ó hàn gbangba nínú iṣẹ ìwádií yií pé ewì gẹgẹe bí ète mú àwọn ọ̀tá nítorí ọ̀nà tí wộn gbà lò ó fún ìdệrùbani, ìdájàsílẹ̣, ìtannijẹ, ìránnilétí, ẹ̣ẹ̣ àti àyệsí. İgúnlẹ iṣẹ ìwádií ni pé idà olójú méjì ni ewì jệ. Bí a șe le lò ó gẹgẹ bí ète ìdógunsílẹ náà ni a lè lò ó láti pẹrọ̀ ogun. Nítorí náà, ewì tí í șe ogún ìbí Yorùbá ni a le șàmúlò láti dènà tàbí pệtù sí aáwộ kí ó tó di ogun lộnà àti mú àlàáfía àti ìdàgbàsókè bá àwùjọ.
\end{abstract}

\subsection{Ogun Àti Ète Ogun Jíjà Láwùjọ Yorùbá}

Kò sẹ́ni tó le sọ pàtó ìgbà tí ogun jíjà bẹ̀rẹ ní àwùjọ ènìyàn. Àșà kan tó kárí gbogbo àwùjọ àgbáyé ni. Nígbà tí èrò ộwó ènìyàn méjì kò bá dọ́gba, tí ọ̀kan kò gbà fún èkèji, tí wọn kò sì șetán láti yanjú ẹ̀ ní ìtùbí-ìnùbí, dandan ni kí ohun náà di ìjà, èyí tí ó sì le yộrí sí lílé ẹ̣mí ara ẹni kiri. Bí èyí bá ti șẹlệ, ọ̀rọ ti já sí ogun nìyî́. Bí a bá wò ó láti inú itán ọjộun ilẹ Gíríikì, oríṣî́ríșií ni àwọn ogun tó gbajúmọ tí àwọn ènìyàn àwùjọ náà bá àwọn ìran miíràn àti àwọn ara wọn jà. Lára àwọn ogun tó gbajúgbajà tí wọ́n jà ni Ogun Troy, Ogun Corinthian láàrin 395 BC sí 387, Ogun Persia 499 BC sí 488 BC, Ogun 
Peplonnesia 431 BC sí 404 BC (Fitzgerald, 2017), Ogun ilẹ Asia, bẹ̀rẹ̀ lọ́dún 334 BC àti wíwọ ilẹ Egypt láàrin 332 BC sí 331 BC (Pomeroy, 2004) àti bẹẹe bẹe lọ. Bákan náà nínú Bíbélì, oríșiíríșií ogun ni ó wáyé láàrin àwọn ọmọ Ísráẹlì àti àwọn ộtá wọn gbogbo. Lára àwọn ogun mánigbàgbé inú Bíbélì ni ogun Ábrámù àti àwọn ará Sínái (Bábílónì) (Jẹ́nẹsísí 14), Ọba Fáráò àti àwọn Ísráẹlì (Ẹ́kísódù 14), Ísráẹ́lì àti àwọn Ámálékì (Ẹ́ kísódù 17; 8-16), İtakora àwọn ọmọ Ísráẹlì pẹ̀lú ara Mídiánì àti Móábù (Númérì 31:11-11), Ísráẹ́lì àti ara Jẹ́ríkò (Jọsụuà 6), bí àwọn ará Fúlístínì șe gba Àpótí-Ẹ̀rí (1 Sámúẹ́lì 4:1-11), (Shiffered 2015) àti (Cleretian Publication 2003). Bákan náà ni ợọ șe rí nínú Quran. Lára àwọn ogun tí a rí kà nínú Quran ni (Ogun Badr; Quran 8:5-8), Ogun Uhud (Quran 3:169), Ogun Khandaq (Moat) tabí Ahzab (Quran 33:1011), Ogun Khaibar (Quran 48:18) àti Ìborí Makkah (Quran 17:81). Ėyí fi hàn pé láti ìgbà ìwáșẹ ni ọmọ ènìyàn tí ń bára wọn ja ogun, kò sí ibi tí a kì í tí kó adìẹ àlẹ́ sì ni ợọ̀ ogun jẹ́.

Bí àwọn wọ̀nyí tilẹ jẹ́ ogun ọlộjọ́ pípẹ́, àwọn ogun kan wà tí ọjọ́ wọn sún mọ́, bákan náà ni àwọn kan ń lọ lộwọ́. Lára àwọn ogun tí ojộ wọn kò jìnnà tó àwọn tí a tọ́ka rẹ̀ lókè ni Ogun Abẹ́lé Ilẹ Amẹríkà (1861-1865), Ogun Franco-prussian (1870-1871), Ogun Àgbáyé I àti II (1914-1918 àti 1939-1945) àti Ogun Abẹ́lé Ilẹ Nàijíría (1967-1970), wo Gate (2001) àti Townshend (2000) fún àpẹerẹ síwájú sí i. Lára àwọn ogun tó ń lọ lộwộ lágbàáyé ni Ogun Abẹ́lé orílệ-èdè Sòmálía (1991 di àsikò yìi) àti Ogun Abẹlé Orílệ-èdè Ààrin Gbùngbùn Ilẹ̣ Adúláwọ̀ (2012 di àsìkò yî́). Kí ilẹ̣ Yorùbá tó dara pọ mọ́ àwọn ẹ̀yà miî́ràn láti di orílẹèdè Nàijírià ni ogun ọlọ́ kan-ò-jọ̀ kan ti máa ń wàyé láàrin wọn. Lára àwọn gbajúgbajà ogun tó wáyé ní ilẹ Yorùbá ní Sẹ́ńtiúrì Kọkàndínlógún ni Ogun Òwu (1813-1814 àti 1821-1826), Ogun Èkìtì Parapọ (Ogun Kírìí), Ogun Dahomey (1726-1823), Ogun İjàyè (1860-1862) àti Ogun Bátẹ dó (Arógundádé, 2017).

Ẹwẹ̀, Yorùbá kò fi ọwọ́ yẹpẹrẹ mú ọ̀rọ̀ ogun rárá. Ėrò, ìgbàgbọ́, àșà, ọ̀ọ̣ ẹnu, èsìn àti àwọn ọ̀nà ìgbé-ayé wọn gbogbo fi èyí hàn. Yorùba bọ wộn ni; "Ogún níi șini mú, èpè kì í șini jà". Ohun tí èyí fi hàn ni pé ogun kò mọ ojú ẹnikan bóyá èniyyàn lộwọ́ nínú rẹ̀ tàbí kò lộwọ́ nínú rẹ̀. Ėyí tún fi ìjànbá tí ogun ń șe hàn. Yorùbá a tún máa sọ pé, "Ẹni tí kò mogun níi sọ pe kí ogun ó dé, ogun kò rí bí ìyan bẹẹ̀ ni kò rí bí ẹ̀kọ̣”. Ėyí tộka sí pé ọ̀rọ̀ ogun kì í șàwàdà, ọ̀ọ̀ ìparun ìran, èyà àti àwùjọ ni. Bí ọ̀rọ ogun șe lágbára tó Ifá kò fi ojú kékere wo ìjànoá, ìparun àti ị̀òfò ẹmí tí ó máa ń mú dání. Ẹsẹ ifá kan sọ̀rọ̀ nípa ogun nínú Yémitàn àti Ogundélé (1970):

Apá ẹran ń bẹ lộwọ́ Lánlọṣe,

Agọ màrìwò ń bẹ lộwọ́ Làrùba.

Mo f'ògo,

Mo r'ógo, 
Mo wò'gbẹ̀hìn ọ̀ràn bí yíò ti sunà, sùnà sí.

Èmi wò gbẹ̀hìn ọ̀ràn sunà, sùnà sí:

L'ó dífá f'ọ́ ba l'Éwìi Adó.

Ológoșẹe, àwo wọn l’Óde Àgéré;

Àrẹrẹ̀ kosùn, awo Òkè Ìjerò;

Èbùrẹ jẹgìjẹgì, awo ọrùn èbè,

Awo inú poro oko:

Ló dífá f'ọ́ba l'Áròde Òyọ́

Ó dìgbà kiíní,

Ọba Ọlọ́yọoọ ń gbógun rÒde Èwí:... (Ojú Òșùpà: 70-76)

Ninú ẹse Ifá yìí, Ológbòjìgọ̀lọ̀ lawo Èwí Adó, òun náà ló sì bá a sa Ifá tí apá ogun kò fi ká ilú rẹ̣ lásìkò tí Ọlọyọọ̣ fẹ́ láti ja ilú rẹ lógun fún ìgbà àkọ́ kọ́. Torí pé ijànòa ni ogun jệ, Olộyọoọ dẹ tàkúté obìnrin sí baba aláwo yií, ìyẹn sì fún àwọn ère agbára rẹ̀ ní èèwọ̀ jẹ tí ọwộ ộtá fi tẹ Ėwí Adó àti àwọn ènìyàn rẹ̀. Esẹ Ifá yî́ ń tọ́ka sí i pé òpin ợtá láàrin ọmọ ènìyàn ni ogun jệ. Dídẹ obìnrin síni sí jẹ ọ̀ kan lára àwọn ète tí àwọn jagunjagun àtijọ́ máa ń șàmúlò láti jagunșégun. Ó tún fi hàn pé ète ogun jíjà kò pín sí ibikan șoṣo. Orísiîríșií ọ̣nà ló le gbà yọ.

Orísiî́ ogun méjì ni Adéoyè, (1979:259) tọ́ka sí; ogun àdájà àti ogun àjàkúakátá. Ogun àdájà ni ogun ayé tí ẹnìọ̣ộkan ń dá jà lábẹ aṣọ, tí ó șe é șe kí ẹnikèjì má gbọ́ si. Àpẹerẹ èyí ni ogun ayé, ogun àjẹe, ogun elénìní àti bẹeẹ bẹeẹ lọ. Ogun àjàkúakátá ni ogun ọ̀ kọ àti àdá, ogun ợà àti ỉbọn. Ėyí kì í șe ogun ànìkanjà rárá, àjọjà ni. Àpẹẹrẹ ogun yî́ ni àwọn Ogun Èkìti Parapọ̀, Ogun İjàyè, Ogun Òwu, Ogun Kírìí àti bẹẹe bẹeẹ lọ tí a ti mẹnu bà lókè. Adébọ̀wálé, Olúmúyìwá àti Așíwájú (2018) àti Fáșehùn tilẹ tọ́ka rẹ̀ pé oríṣî́ ogun kan ni ogun ẹnu náà jẹ. Àwọn onímà yî́ náà gbà pé Oríșiíríșií ni ète tí àwọn jagunjagun ìgbàanì máá ń lò láti já ogun. Lára wọn ni ríró èso igi, wíwọ̀ lú lójijì, odi mímọ àti títan ọtá mú. Lára àwọn ohun tí wộn fi le tan ọ̀tá mú ni oúnjẹ, dúkíá, obìnrin, èdè àyàn (ohùn ìlù), èéfín àti bẹeẹ bẹẹ lọ. Àwọn ète miíràn tí Dáramọ́la àti Jẹ́ jẹ́ (1975) tộka sí ni kòtò gbígbẹ sí ibi tí ọ̀tá kò mọ tệlẹ̀ ti ó ti lè rọ́ lù ú àti șísáná bọlé oọtá láìòtệlệ. Arógundádé (2017) tilẹ șe ọ̀pọ̀ àlàyé lórí pé ète oríșiíríșií ni àwọn è̀yà Yorùbá șe àmúlò nínú àwọn ogun tí wọ́n jà ní Sẹ́ntiúrí Kọkandínlógún. Awẹe (1975) tún șàlàyé síwájú sí i pé oríkì àwọn jágunjagun tí a sọ di ohun ìdánimọ wọn, tí àwọn onílù ogun wọn fi máa ń kì wộn lójú ogun jẹ ọ̀kan pàtàkì nínú ète tí àwọn jagunjagun fi máa ń dọdẹ ara wọn. Àpẹerẹ pàtàkì kan tí Awẹ́ (1975) tộka sí ni Ogun Jálumi (1878) níbi tí Fábùnmi àti àwọn ọmọ ogun Èkìtì ti fi ohùn ìlù oríkì ọmọ Balógun İbíkúnlé, A kíntọ́lá "Kìnìun Oníbùdó” (269-270) tan Òsì Balógun İbàdàn, Ìlọ̀rí àti àwọn ọmọ ẹ̀yìn rẹ̀ mú. Bí a bá le fi oríkì tí a fi èdè àyàn gbé kalẹ tan jagunjagun kan mú gẹgẹ bí ó șe ș̣lẹ nínú àlàyé tí Awẹ șe yìí, a jệ pé ète ogun 
kan gbòógì ni ewì jệ. Finnegan (2012) náà kò șài tọ́ka sí i pé àwọn ènìyàn ilẹ Adúláwọ̀ máa ń lo èwì láti fi șe kóríyá fún àwọn jagunjagun lójú ogun.

Yàtọ̀ sí pé a fi ewì tan jagunjagun mú bí Awẹe (1975) șe tọ́ka sí i yìi àti pé a le fi șe kóríyá gẹgẹ́ bí Finnegan (2012) șe sọ, àwọn ìtàn ogun mìiràn níbi tí a ti șe àmúlò ewì gẹgẹe bí ète ogun tún fi hàn pé a le fi ewì dẹ́rù bá ộtá, a le fi tani jí, a le fi da nǹkan rú mọ́ ộtá lójú, a le fi ránni léti ète tí a ti pa kalẹ de ọ̀tá, a sì le fi dệrọ ìjà. Ộwộadé (2018) șe àlàyé pé a máa ń fi orin șe ìpẹ̀, kéde ogun, șáátá ọ̀tá, fi ẹ̀hónú hàn àti șe ìkị̀ọ lójú ogun. Ohun kan tí ó tún șe kókó láti kíyè sí nípa àlàyé Awẹ yìi ni pé ewì lágbára torí pé ọ̀rọ̀ ni a fi gbé e kalệ. Yorùbá bọ̀, wọ́n ní, "Ojọ́ tí ogun yóò tú İkìrun, ộọ̀ ló tệlẹ̣ rẹ̣". Bí èyí bá rí bẹeẹ̀, a jẹ́ pé ìrúfẹ ọ̀rọ̀ tí ó lágbára láti tú odidi ìlú kì í șe ọ̀rọ̀ șákála kan lásán, ọ̀rộ tó nípa lára olùgbọ rẹ̀ ni. Gẹegẹ bí ó șe jẹ pé èdè tó nípa lára olùgbọ́ ni Fábùnmi àti àwọn ọmọ ogun Èkìtì fi tan odìdi Òsì Balógun Ìbàdán àti àwọn ọmọ ogun rẹ̀ mú. Kí ọ̣ọ̣ tó le nípa lára ju ợọ̣ lásán lọ, a jẹ́ pé èdè afìmộsílárahan tíí șe èdè-ọnà ni a fi gbé irú ọ̣ọ̣ náà kalẹ. Bí a bá sộrọ nípa èdè ișẹ ọnà, èdè ewì náà ni à ń tọ́ka sí torí pé èdè ewì yàtọ sí èdè ojoojúmọ́, inú rẹ sì ni fífi èdè pàrokò wộpọ sí jùlọ (Riffaterre, 1978). Fún ìdì èyí ó yẹ kí á le sọ̀ọ̀ nípa ewì àti bí ó șe máa ń mú àwọn olùgbộ lọ́ kàn.

\subsection{Ewì àti Èdè Ewì}

Orúkọ mî́ràn fún ewì ni àròfọ̀. Ọ̀kan lára àwọn ẹyà tí lítíréșọ pín sí káríayé ni ewì jẹ. Ợnà láti fi èrò inú ẹni hàn ní ìlànà onílàjilà níí șe pẹ̣lú. Ėdè inú ewì a máa ki, kì í gùn jù, kò sí àyè fún ìfợọṣòò nínú rẹ̣, aboyún ợọ̀ ni ewì máá ń jẹ. Kí àșà mọ̀-ọnkọ-mọ̀-ọ́nkà tó dé ni ẹyá Yorùbá ti ń ké ewì, irúfẹe ewì yî́ ni a mọ̀ sí ewì alohùn. Àwọn ọnà mẹta pàtàkí tí Ogúndèjí (1991) tộ ka sí pé a le pín ewì alohùn Yorùbá sí nígbà tí a bá lo ìwéhùn àti ộfun șíșe gẹgẹe bí òșùwọ̀n ni àrángbọ́, ìsàré àti orin. Àrángbọ́ ni ewì tí a gbé jáde nígbà tí ìlànà àgbéjáde rẹ kò bá yàtọ sí ìgbà tí à ń sợọ ojoojúmọ́. Àpẹerẹ irúfẹ èwì bẹẹ ni oríkì, ơfọ̀, àlọ àpamọ, àrọ̀, ẹsẹ Ifá àti òwe. İșàré ni ewì tí a gbé jáde nígbà tí à ń șe ộfun tàbí rán ộfun kí á tó gbé e jáde. Àpẹerẹ èyí ni ẹ̀àa egúngún, ẹkún ìyàwó, ijálá, olele, yùngbà, rárà, ìgbálá àti bẹẹ lọ. Orin ni tìrẹ ni ìlànà rírán tàbí díndín ohun èyí tó gunpá ju àwọn méjì ìsáájú lọ, èyí ló sì fa kí ó șe e gbè, jó, lúlù tàbí șápẹ sí dáradára. Gẹgẹ́ bí èrò Sotunsa (2005), ọ̀kàn pàtàkì tí a kò gbọ̀ dọ yọ sílẹ nínú ọ̀nà tí ewì alohùn pín sí ni èdè àyàn jệ. Sotunsa (2005) sọ pé bí àrángbọ́, ìsàré àti orin șe dá dúró gẹgẹe bí ẹ̀yà ewì alòhùn Yorùbá ni ó yẹ kí èdè àyàn náà dá dúró. Ėró yií ló mú wà gbà pé dipò mẹ́ta tí àwọn onímọ̀ lítíréṣọ ị̀áájú pín ewì alohùn Yorùbá sí, mệrin ni ó yẹ kí ó jệ.

Èdè ewì tún jẹ́ àrímáleèlọ àwòpadàsẹyìn nínú àgbékalẹ èwì Yorùbá. Èdè gan-an ló máa ń șọ bí akéwì șe dáńgájía tó. A máá dùn ún gbộ létí ju èdè ojoojúmọ́ lọ. Ėyí ló fà á tí àwọn ìpèdè tó wà nínú àkámọ́ wọ̀nyí fi dùn ún gbọ́ létí 
ju àwọn tí kò sí nínú àkámọ́ lọ; Àlàkẹe (Alálàkẹ́), Àdùnní (Aládùnní), òjò (eji), ọmọ olòșì, (olòșì ọmọ), ilẹ̀ ń șú lọ (ọjọ ń rebí tàná/òòrùn ń rebi àtiwọ) àti bẹẹ bẹẹ lọ. Gbogbo àwọn ìpèdè tí a fi sínú àkámọ wọnnyí jẹ èdè ewì, torí èyí ni wộn fi dùn ún gbọ́ létí ju àwọn tí kò sí nínú àkámọ́ lọ.

Bí a bá wáá wo àwọn aáwọ̀ tó máa ń șẹlẹ láwùjọ, kékeré kọ́ ni ipa tí èdè ewì ń kó nínú bíbẹ̀rẹ̀ wọn. Yorùbá bọ̀ wộn ní, "Ọwọ níi șíwájú ijó, orin níí șíwájú ọ̣tẹ̀”. Bákan náà ló jẹ́ pé ewì a máá kó ipa tó jọjú nínú ète ogun jíjà gẹgẹe bí a ti șe sọ. Báyî́, a ó gbìyànjú láti wo bí a șe lo ewì gẹgẹ́ bí ète nínú àwọn àșàyàn ìàn ajẹmógun tí a yàn láàyò.

\section{0 Àgbéyè̀wò Ewì Gẹ́gẹ bí Ète Ogun Jíjà}

Ní báyî́, a máa șàgbéyẹ̀wò ewì gẹgẹ́ bí ète ogun, irúfẹ́ ewì tí a lò, bí a șe lò ó àti ìdí tí ète náà șe mú ọ̀tá tí a pa á dè, tí așàmúlò ète ewì náà sì șe fi beẹẹ șẹgun ọ̀tá rẹ̀. Láti inú àwọn ìtàn ogun tí a sọ ni a ti fa àwọn ohun tí a mẹ́nu bà wọ̀nyí jáde.

\subsection{Orin Ogun}

A ti șo pé orin níi șíwájú ọtẹ̀. Yàtọ sí èyí, àwọn jagunjagun a máa șe àmúlò ọ̣ọ̀ lọpọ̀ orin ìdẹ́rùbani láti fi șe àfihàn bí ọmọ ogun wọn șe pọ tó èyí tí ọtá kò níi le dúro dè àfi kí ó sálọ. Oríșìírișií ni àwọn órin yìí. Kódà a rí nínú àwọn jagunjagun Yorùbá tí ìtàn șọ pé fúnra wọn ni wọ́n máa ń lu ìlù ìṣẹgun lọ sí ogun. Lára àwọn orin tí àwọn ológun máa ń kọ lọ sójú ogun nìyí:

a. Múnimúni dé

Ará Ìbàdàn dé

Orò mọnigbénimì

b. Kò sệni tó lè dúró

À fòkè, à figbó

d. Lílé: Gídígbò gídígbò

Ègbè: $\quad$ e yà

Lílé: E wí fálejò kó lọ

Ègbè: Ẹ fi șașara bàgbo

e. Bọ́wọ́ bá baláṣejù

Pípa ni ẹ pá

Ká rohun jệba lọ́la 
ẹ. Orí mobà ní ó kun

Kòtò gìrìwò tó ń bẹ lÁkánrán

Orí móbà ní ó kun

Orin àkọ́kọ́ òkè yìi jẹ́ orin ìdẹ́rùbani torí àwọn ọ̀ọ̀ adẹrùbani tó wà nínú rẹ̀. Àwọn wọ̀nyí ni "Múnimúni" àti "Orò mọnigbénimì" "Múnimúni” gẹ́gẹ́ bí a șe lò ó nínú orin yìi ń tọ́ka sí "ẹni tí ó máa ń múni lẹ́rú”. Òun náà ni a tún pè ní ará İbàdàn nínú ìlà kejì. Òun náà ni a pè ní "Orò mọnigbénimi”. Òrìsà ni Orò jệ. Kò sí ohun méjì tí Orò ń șe ju pé kí ó gbé ènìyàn lọ. Bí Orò bá gbé ẹnìkan, Orò pa onítộhún ni. Orò yî́ ni a fi pe ará Ìbàdàn gẹgẹ́ bí ẹni tó jẹ́ pé mímọni rẹ̀ kò pé kó máșe gbé ni mì. Pípe ará Ìbàdàn ní Orò níbí jẹ́ àfiwé ẹlẹọộ. İwà kan tí a fi wé ti Orò nínú ìwà ará Ìbàdàn níbí ni bí ó șe jẹ́ pé mímọni tí ará İbàdàn mọni kò sọ pé kí ó má șe múni lệrú tàbí pani. Nínú orin kejì ni a ti sọ pé òkè àti igbó nìkan ni ó le dúró bí ó bá gbọ ìró ogun. Bí a șe sọ pé òkè nìkan ni ó le dúró nínú orin yî́ jẹ ìfohunpènìyàn torí pé a fi àbùdá dídúró wọ òkè àti igbó bí ẹni pé èniyàn ni wọn. Ệẹ̀, òkè àti igbó tí ó tún le dúró de ogun níbí ni a tún le fi ojú àfidípò wo. Ohun tí òkè àti igbó le dúró fún nínú ìtumọ ijìnlẹ orin yîi ni akọni ènìyàn tí kò le rí ogun sá gẹgẹ́ bí òkè àti igbó tí kì í sá fún ogun. Torí náà, ìì̀ọ ni orin yì ń șe fún gbogbo ènìyàn tí kò bá rí bí òkè àti igbó láti tètè máa sá lọ torí pé ogun le mú wọn.

Nínú orin kẹta, ìpèdè ìdájàsílẹ tí àwọn ọkùnrin tó tó ọkùnrin máa ń fi pilẹ̀ jàgídíjàgan ni "gídígbò gídígbò" jẹ́. İdáhùn tí àwọn elégbè dáhùn pé "E e yà" ń tộ́ka pé àwọn ti șe tán wàhálà náà. Ėyí ló sì mú ẹni tí ó ń lé orin tún sọ pé, "E wí fáléjò kó lọ̣". Ėyí ń tộ ka pé kí ọmọ àlejò tí kò mojú ilẹ tètè máa sálọ torí pé kò mojú ilẹ bí ọmọ onílé. Àwọn elégbè sì tún dáhùn pé, "Ẹ fi șașara bàgbo". Eyọ ọwọ̀ ni Yorùbá tún ń pè ní șașará. Àwọn àgbo òògùn ìkà kan wà tó jẹ́ pé șașara ni wọ́n fí máa ń lò ó. Àpẹerẹ àwọn òògùn bẹẹ ni òògùn fífi oyin tani, dída ìgbóná sílẹ, ara títa tàbí òògùn ệfộjú. Torí náà, agbò tí àwọn elégbè ní kí wộn ki ṣașara bọ jệ àgbo òògùn ìkà tí Yorùbá fi ń jagun. İránnilétí òògùn lílò fún ọ̀tá ni orin yìi jệ. Orin kẹrin jẹ ìránnilétí ohun tí ó yẹ kí ọmọ ogun șe fún aláșejù. Ohun tí orin yî̀ ní kí wộn șe fún aláṣejù ni pípa, kí wộn le rí ohun jẹ̀bà lộla. Ó yẹ kí á béèrè pé șe ẹ̀à Yorùbá máa ń jẹ ènìyàn ni wọ́n fi sọ irúfẹ ì̀èdè yìi. Ėyí kò rí bẹẹè, ohun tí wọn ń tọ́ka sí ni pé àwọn yóò pa aláșejù bí wọ́n șe máa ń pa ẹran bí ewúrẹ tí wọon fi ń jẹun. Orin tí àwọn Àgbẹ́kọyà kọ ní inú ìjà owó orí ní ìú İbàdàn àti àwọn agbègbè rẹ ni orin karùn-ún yî́. A ó kíyè sí i pé àwọn jagunjagun Àgbẹ́kọ̀yà sọ nínú orin yìi pé kòtò kan gìrìwò tí ń bẹ ní Àkánrán, orí àwọn ọọ̣pàá móbà tí àwọn bá pa ni yóó kún un. Kò rọrùn kí orí ènìàn kún kòtò gìrìwò tó wà ní Àkárán, torí náà, àsọdùn lásán ni èyí. İdẹ́rùbọtá lásán ni. Șùgbọ́n àwòrán tí ìlò èdè yî́ ń yà sí wa lọ́kàn ni bí àwọn ènìyàn (móbà) tí wọn yóò pa yóó șe pọ̀ tó. 
Ètè láti fi dẹ́rù ba ộtá ni àwọn orin wọ̀nyí. Bí ọ̀tá tó bá lójo, tí kò gbáradì, tí kò múra sílẹ dáradára bá gbọ́, yóò sálọ, kò sì níí dúró. Ėyí yóò sì mú kíkẹrú àti kíkẹrù rọrùn fún àwọn tó gbé ogun náà wá ká wọn mọ́lé. Ộ kan lára oríșî́ ewì alohùn Yorùbá ni orin, bí a șe gbà lò ó lọgangan ipò yìi ló jẹ́ kí á mọ̀ pé ète ogun ni.

\subsection{Bí Așawo Șe Lo Oríkì Eléńre Láti Fi Bẹ Ẹ Nígbà Tí Àjùwọ̀n Àjàká Bẹ́ Orí Rè}

Gẹ́gẹ bí Johnson (1921) șe sọ, Àjùwợn tí àlàjẹ rẹ̀ ń jẹ Àjàká ni Aláàfin tí ó jẹ lẹyỳn tí Ọ̀rànyàn gbésẹe. Oníwàtútù ni ọba yî́ nígbà tí ó kộ kọ dórí oyè. Ėyí ló jẹ́ kí oọ̣ọ̣lọpọ̀ àwọn ilù rí i fín, tí àwọn ogun İbàrìbá, Fúlàní àti Òwu kò sì jẹ kí Ợyọ ó gbádùn. Báyî́ ni àwọn Ợyọ kọ ọ̣ tí wọ́n sì fi àbúrò rẹ Aláàfin Sàngó jẹ. Leéyìn tí Aláàfin Sàngó gbésẹ̀, Ọ̀yọ́ ráńṣé pe Àjàká látí wá padà jọba. Oun sì ni Aláàfin tí wọ́n tún fi jẹ lệyìn tí wộn ti rọ̣ ọ̣ lóyè. İgbà ẹẹejkejì Àjàká yî́ yàtọ pátápátá torí pé ogun ló ń fi gbogbo ìgbà kó àwọn OỌyọ́ lọ, èyí sì ni gbogbo ìlú fi gbà pé ọba tó burú jọjọ ni. Àjàká kó àwọn jagunjagun àti àwọn babaláwo tó gbówọ́ jọ, orúkọ Bașọ̀run rẹ ni Eệrìndínlógún-àgbọn-kòșé-dífá. Àwọn jagujagun Àjàká ni Olúgbọ́n, Arẹ̀sà, Oníkòyí àti Ajaguńlá. Àwọn babaláwo rẹ sì ni Atagbọ́n-in, Àbìtìítì Oníșègùn, Pakú, Tẹ̀tẹ-ò-nírú, Yaanà, Ọkọ-àdán, Ègbẹgí, Àlàrí Baba İṣègùn àti Eléńre.

Nígbà tí àwọn babaláwo wọnyí ti pẹ púpọ̀ ní ojú ogun, aáyun àwọn ìyàwó wọn ti yun wọ́n, wọ́n sì bá Àjàká sộrọ pé kó pa ogun tì. Torí ẹrú àti ẹrù Àjàká tí ó ń lé sí, àti pé kí àwọn babaláwo wọ̀nyí má baà șe tẹlòmíràn bí wộn bá dé ilé, Àjàká kò gbà pé kí wọn ó lọ. Àwọn náà jệwọ́ fún un pé babaláwo ni àwọn. Atagbọ́n-in, Àbìtibítì Oníșègùn, Pakú, Tẹ̀tẹè-nírú, Yaanà, Ọọ-àdán, Ègbẹ̀gí àti Àlàrí Baba İșègùn bá bẹerẹ sí níi șubú lulẹ̀ lộkọ̣ộ kan tí wộn sì ń pòórá. Ó ku Eléńre nìkan. Àjàká ní kí òun náà șe bẹẹ tàbí kó pada sógun bí bẹẹ kọ́, òun yóó bẹ orí rẹ fún Ògún. Eléńre kò dá a lóhùn, ó ń wo itú tí ọba fẹ́ pa. Àjàká pàșe kí wọ́n bẹ orí aláìgbọàn náà. Gbogbo bí wọ́n ti ń gbìyànjú láti fi idà, àdá, ộ kọ̀, agada, òkúta ńlá pa Eléńre, pàbó ló já sí. Àjàká bá fi oggbọ́n kún ợọ náà, ó ti ara ìyàwó Eléńre (Ìjàẹhìn) mọ àșírí agbára rẹ̀, wộn sì lo fọ́nran bẹẹe kan șoṣo láti fi bẹ́ orí Eléńre. Bí wộn ti bẹ́ orí yî́ tán ni orí fò pọ̀n-ùn sí ơrùn ọwộ ộtún ọba, ó sì di oríșà tí kò jẹe kí ọba gbádùn. Gbogbo oúnjẹ tó yẹ kí ọba máa jẹ, ẹnu orí Eléńre ló ń bọ sí. Ọba bá bẹrẹ sí níí ránșẹ sí gbogbo àwọn babalàwo láti bá a lé orí náà kúrò ní ơrùn ọwọ́ rẹ̣. Gbogbo àwọn awo tó ń wá yî́ ni kò rí orí náà lé kúrò. Nígbà tó yá, Àjàká ránșẹ sí Așawo, tí í șe ọmọ Ayé, tó tẹ ilú Ayétẹ àti Ìdèrè dó. Olọgbọ́n ni awo yî́, ó ti gbọ́ ìròyìn wàhálà náà, bí ó sì șe yọ sí ààfin Àjàká, tí kò tilẹ tí ì fojú kan Àjàká àti orí Eléńre ni a gbọ́ pé Aṣawo ti bệrẹ̀ sí níí ki oríkì Eléńre. Oríkì yî́ náà sì ni ó tú u fó pé ó ti dé sí Ọ̀yọ Àjàká. Ó pộn ọn lé, ó sì rọ̀ ộ pé kó máṣe bínú. Lára 
àwọn oríkì tí a gbọ́ pé Aṣawo șe àmúlò ni oríkì àwọn babaláwo gẹgẹ bí ó șe jẹyọ nínú ewì ìsàlẹ yìí.

Eléńre awo tó mọ dídá ọwọ́

Eléńre awo tó mọ ètìẹ alẹ̀

Eléńre awo tó mọ̀ karara ẹbọ

Eléńre awo tí ì í parọ

Eléńre awo tí ì í șèké

Eléńre awo tì í í șojo

Ò bá jèbùrẹ́ awo olùgbẹ́bẹ̀

Torí awo ní gbáwo nígbùn-únwọ́

Báwo ò gbáwo nígbùn-únwọ́

Awo a tẹ́ awo a ya... ${ }^{1}$

Bí a bá wo àwọn ìpèdè òkè yií, ìlà mẹwàa ni ó ní. A le pín àwọn ìlà ewì yií sí ọ̀nà méjì gbòòrò; abala oríkì (ìlà 1-6) àti abala ẹ̀bẹ̀ (ìlà 7-10). Nínú abala oríkì ni a ti șe àpọ́lé Eléńre nípa fífi gbólóhùn aláwìitúnwí ìhun gbé e kalẹ̀. A șe àwítúnwí orúkọ Eléńre níbẹ̀. Ėyí tộka sí i pé Eléńre ni òsùnsùn afọ̀ tí Aṣawo ń pè lemộlemọ́. Yorùbá nígbàgbọ́ nínú pípe ohun kan lemọ́lemộ. Èyí sì ni ìdí tí a fi máa ń șe àwítúnwí orúkọ àwọn ẹ̀mí àirí tí apọoộ fẹ̣ kó rọ̀ wá ran òun lộwọ́. Bákan náà, Yorùbá gbà pé gbọmọgbọmọ ni à ń ránfá adìtí. Kì í șe pé Eléńre dití șùgbọ́n ó kọtí ọgbọnhin sí àwọn babaláwo tí Àjàká ti pè șáájú. Èyí ló fa dídárúkọ rẹ̀ léraléra gẹgẹ bí Așawo ti șe yìi. Ìdáláre tún wà bí a bá tún abala oríkì yìi pín sí méjì bí a bá lo bí àwọn gbólóhùn inú abala náà șe bá ara wọn dọ́gba gẹgẹ́ bí òșùwọ̀n. Abala àkọ́kọ́ nínú abala oríkì yìi ni ìlà kìnín-ní sí ìkẹta (ìlà 1-3). Àwọn gbólóhùn inú abala yìi bá ara wọn dọ́gba nínú ìhun, èyí sì jẹ kó rọrùn fún "dídá ọwộ", "ètìtẹ alẹ̣" àti "ikara ẹbọ" láti bá ara wọn rìn. A tún le rí "dídá ọwộ", "ètìtẹ alẹ̣" àti "ikara ẹbọ" gẹgẹ́ bí òșùwọ̀n pàtàkì láti șe ìgbéléwọ̀n babaláwo ojúlówó. Bákan náà, "tí ó" (tó) inú àwọn ìpèdè yî́ jẹ́ atọ́ka gbólóhùn ijộhẹn tí ó máa ń fi òtítọ́ inú gbólóhùn (ộộ) tí kò le di irọ́ láéláé hàn. A șe àmúlò àbùdá yî́ láti șe àyẹesí Eléńre nínú àwọn ìpèdè òkè náà ni. Gbogbo ìwọ̀nyí ń tọ́ ka pé ojúlówó awo tó gbọ́ Ifá dójú àmì ni Eléńre. Ėyí sì jẹ àpọ́nlé fún un.

Apè àpọ́nlé yìi náà ni aṣafọ so mọ́ abala kejì nípa àbùdá àti ìtumọ rẹ̀. Gẹgẹ́ bí a șe fi òtítọ́ nípa Eléńre hàn nínú ìpedè inú àtúnpín àkọ́kọ́ abala kìn-ín-ní nípa lílo atọ́ka gbólóhùn ijọ̣hẹn náà ni a șe fi òtítọ nípa rẹ hàn nínú abala kejì yìi nípa lílo atọ́ka gbólóhùn àyísódì ("ì î" tó jẹ́ àgékúrú "kì î"). A șe àwítúnwí ìhun gbólohùn (\#Awo tí kì í ........\#²) náà níbí. Ėyí jẹ kí àwọn "pa", "ṣe" àti "ṣe"

1 Johnson (1921) kò sọ pàtó oríkì tàbí ìpèdè ẹ̀ bẹ̀ tí Aṣawo șe àmúlò. Ėyí ló mu wa béèrè ọ̀ọ̣ lộwộ Bàbá Fágbénlé Awólộwọ̀ tó jẹ ọmọ ìlú Ayétẹ̀, ẹni tí a gba ohùn yî́ lẹnu rẹ̀.

2 Àmì “\#” yií dúró fún ìbẹ̀rẹ̀ àti ìparí gbólóhùn. 
bá ara wọn rìn. Bákan náà ni "irọ́", "èké” àti “ojo" náà bá ara wọn rìn. İwà burúkú tí Eléńre kò ní tí kò sì le pada ní láéláé ni àwọn gbólóhùn yìi fi hàn.

Abala kejì ni Așawo ti bẹ Eléńre pé kó jèbùrẹ awo olùgbẹ́bẹ. "Jẹ èbùrẹ awo olùgbẹ́bẹ’" jẹ ìpedè kan tó gbajúmọ láàárín àwọn babaláwo láti fi bẹ ara wọn. Ėyí fi hàn pé ẹ̀ bẹ ni ìpèdè náà dúró fún. Așawo kò tún dákẹ bí ó șe pa òwe pé “... awo níí gbáwo nígbọ̀wọ́, bí awo ò gbáwo nígbọ̀wộ, awo a tẹ́, awo a ya”. Ohun tí Așawo sọ níbí ni pé awo ni olùrànlộwọ́ awo tí awo fi í șe àșeyọrí àti pé bí awo kò bá ran awo lộwọ́, awo kò le șe àșeyọí. Ohun tí èyí ń tọ́ ka sí ni pé Àșeyọrí Aṣawo wà lộwọ́ Eléńre.

Torí àwọn ìpẹ̀ tó șe yî́, Eléńre gba ìpẹ̀ rẹ. Ó tijú rẹ̀ torí pé kàkà kó sààgùn bíi àwọn awo ị̀áájú, àyẹsí rẹ̣ ló șe. Eléńre náà sì mọ pé bí ó șe jệ pé ọmọ àlè ní ó máa ń rínú tí kì í bí náà ni ó jẹ pé ọmọ àlè ni a máa ń bẹ tí kì í gbà. Bí ẹlẹjọ́ bá sì ti mọ ẹjọ́ rẹ̣ lệbi, kì í pẹ lórí ìkúnlẹ̣ mọo. Orí Eléńre fò kúrò lộwọ́ Àjàká, ó sì di odò Eléńre tó ń șàn ní Ợyọ Àjàká. İyàwó rẹ rí i pé òun ti dalẹ ọọ òun, òun náà sì di odò șùgbọon Eléńre fi í bú pé kò níí le șàn títí ayé.

Kókó ohun tí a fẹ́ láti fà yọ nínú ìtàn yî́ ni pé, ogun tí àwọn awo tó wá șíwájú Așawo kò rí șẹ nípa lílo òògun, àdá, ọ̀ kọ̣, àáké, ộà, èlè àti àwọn nǹkan ijagún mî́ràn ni Așawo fi ète ewì (nípa lílo oríki) șẹe Ẹyà kan tó nífẹeè orúkọ wọn dọ́ ba ni Yorùbá, wọn a sì máá fẹ gbọ́ ohùn ẹni tó máa ń șàyẹ́sí wọn. Ėyí ló jẹ́ kó rọrùn fún Aṣawo láti le șàșeyọrí nínú lílo ètè náà gẹgẹ̣ bí ó ti șe lò ó yìi.

\title{
3.3 İtàn Ọùnrin Kan Tí İyàwó Rẹ̀ Gbà Là
}

Nínú Odúnjọ (1971), ìtàn àtẹnudẹ́nu nípa arákùnrin kan tí kò ní ìgboyà jẹyọ níbẹ̀. Arákùnrin yî́ ni òun àti ìyàwó rẹ̀ dìjọ ń rin ìrìnàjò láti lọ șòwò. Àsìkò yî́ ní ilẹ Yorùbá jẹ àsìkò tí àwọn agbésùnmọ̀mí ń gbé sùnmọmí kiri, tí wọ́n ń dá àwọn ènìyàn lộnà, tí wộn ń kó wọn lệrù, tí wộn sì tún ń kó wọn lệru. Kí ìrìn àjò wọn le já sí ìrộrùn ni ọkọ obìnrin yìi fi múra ogun àti òògùn kúrò nílé. Nígbà tó yá nínú ìrìn àjò wọn, àwọn agbésùnmọ̀mí kan dá wọn lọ́nà. Sí ìyàlệnu aya ọkùnrin yî́, ọkọ rẹ̀ tó ti rò pé gbogbo òògùn tó dì mọ́ra ti tó o láti bá àwọn agbésùnmọ̀mí náà jà, kí ó sì șẹ́gun wọn bá bẹ̀rẹ̀ sí níí gbọ̀n pẹ̀pẹ̀ torí ojòra àti ẹ̀rù tó bà á. Bí ìyàwó șe rí ọkọ rẹ̀ báyìí, ó yanú kótó, ó sì bẹ̀rẹ̀ sí níí sọ pé:

\author{
Máa gbọ̀n \\ Máa gbọ̀n \\ Ọkọ mi máa gbọ̀n \\ Bóo ti ń gbọ̀n tóo fi ń pogún \\ Bóo ti ń gbọ̀n tóo fi ń pọgbọ̀n \\ Olówó orí mi ọkọ mi sá máa gbọ̀n bẹẹ̣
}


Bí àwọn agbésùnmọ̀mí náà șe gbọ́ báyî́ șe ni wọ́n dúró lójììi, wộn sì sá wọgbó lọ. Ėrò wọn ni pé níbi gbígbọ̀n tí ọkùnrin náà ń gbọn ni agbára rẹ̀ wà, pé ó șẹ̀ṣẹ fẹ́ máa ja òògùn ni àti pé inú ti bí i kọjá ààlà ni ó șe ń gbọ̀n pẹ̀pẹ̀ bẹẹe. Ohun tí a fẹ́ láti tộka sí níbí ni pé nípa ète àmúlò èdè ewì ni obìnrin inú ìtàn yìi șe șẹ́ ogun tí kò bá ja òun àti ọkọ rẹ̀, tí kò bá sì kó wọn lệrù àti ẹrú.

Bí a bá șe àgbéyệwò ìlò èdè inú àyọlò yî́, arábìnrin yìi șe àwítúnwí àwọn gbólóhùn "Máa gbọ̀n", èyí ń tộka rẹ̀ pé gbígbọ̀n yìi gan-an ni aṣàfọ̣ fệ kí òsùnsùn afọ̀ rẹ̀ tẹ̀ síwájú láti máa șe. Nípa báyî́ ni ogun yóó fi sẹé "Ọọ mi" tí aṣafọ̀ sọ yî́ jẹ́ kí á mọ ẹni tí ó dojú ọ̀ọ̀ kọ ní pató. Ėyí sì fi hàn bí ẹni pé ìyàwó náà ti mọ ìșesí ọkọ rẹ̀ tẹ́lệ. Èyí ni aṣafọ̀ fi hàn nígbà tí ó tẹ̣ síwájú pé "Bóo ti ń gbọ̀n tóo fi ń pogun" àti "Bóo ti ń gbọ̀n tóo fi ń pọgbọ̀n". Àwọn gbólóhùn yìi jẹ́ gbólóhùn adọggba. Ėyí sì jệ kí aṣafọ̀ le sọ ìrírí rẹ̀ nípa òsùnsùn afọ̀ nígbà tí ó bá ń gbọ̀n. Ohun tí "ogún" àtì "ọgbọ̀n" ń tộ ka sí nínú gbólóhùn wọ̀nyí ni "ènìyàn ogun " àti "ènìyàn ọgbọ̀n". Àwọn ợọ̣ méjèèjì náà jẹ àjùmộrìn ọrộ. Nígbà mìiràn a le tọ́ka "ogún" àti "ọgbọn" bí a bá fi ń ka ènìyàn gẹgẹe bí i ìlộpo "lógúnlógún" àti "lọggbọ̀nlọgbọ̀n". Bí èyí bá rí bẹeẹ, òǹà ènìyàn tí a ní lọ́kan le má mọ ní ogún tàbí ọgbọ̀n nìkan bí kò șe ìlọpò ènìyàn ní ònkà ogun àti ọgbọ̀n. Ní pàtó, àwòrán ọ̣pọ̀ ènìyàn ní "ogún" àti "ọbọ́n" ń yà síni lộkàn. Ėyí sì ni ìdí pàtàkì tí àwọn agbésùnmọ̀mí náà fi sálọ kí ọkùnrin yiî má baà fi gbígbọ̀n rẹ̀ pa wọ́n tán láàárín ișẹe jú àáyá.

\subsection{Lílo Èdè Àyàn Láti Fi Tan Kúrunmí Nínú Ogun Ìjàyè Àti İbàdàn}

İtàn mẹ́ta ợtọọtọ nípa ogun İjàyè ni a sọ níbí. Àkọ́kọ́ jẹ ti Johnson (1921), èkejì ni ti Abiộdún (2013), ẹ̀kẹta ni ti Adébóyè Onígbìndé. Torí pé àwọn ị̣̀ẹ̣ẹ̣ inú ìtàn wọ̀nyí gbệnu léra, níṣe ni a ó máa ti inú ìtàn kan bọ́ sí inú èkejì àti láti inú èkejì bọ́ sínú ẹ̀ kẹta. Ogun İjàyè jẹ́ ọ̀ kan lára àwọn ìtàn ogun tí ó fi lílo ewì gẹgẹ bí ète ogun jíjà múlẹ̀. Ộkan pàtàkì nínú àwọn ogun mánigbàgbé ní ilẹ̀ Yorùbá lápapọ̀ ni ogun yií jẹ́. Ogun yî́ náà ni Johnson (1921) pè ni ogun Bátẹ dó. Johnson tún șe àlàyé pé lára ohun tó dá wàhàlà sílẹ ni bí Iba Olúyọllé ti șe ń rò pé ó yẹ kí ipò òun sún mọ́ ti Aláàfin. Ohùn ìlù rẹ̀ tí àwọn onílù máa ń lù fún fi èyí hàn. Bí àwọn onílù rẹ̀ bá ń kì í, wọn á máa wí pé:

"İba kúkú jọba,

Má șe bí ọba mọ́”

(Johnson 1921:279)

Ewì (èdè àyàn) yií fi hàn pé Iba ti ń șe bí ọba tẹelẹ. Atọ́batệlẹ̀ ni, kò sí ohun tí a le rí lára ọba tí a kò le rí lára rẹ̀. Lótiítộ kì í șe pé ipò ọba kò wù ú șùgbộn ọmọ obìrin ló jẹ́ sí Aláàfin. Ėyí kò sì le jẹ̣ kó șe é șé fún un láti jọba. Báyìi ló bẹrẹ sí níi ta Ààrẹ Kúrunmí lệnu. Kúrunmí tó jẹ́ Ààrẹ-Ọnà Kakaǹfò ilẹ̣ Yorùbá nígbà náà ni ipò rẹ̀ sún mọ́ ti ọba. Ipò yìi kò sì ní ìran. Iba Olúyọllé 
náà le jẹ ẹ́. Ogun İjàyè bẹ̀rẹ̀ nígbà tí Ààrẹ lé Aṣú (Ààrẹ Ládìgbòlù) olóyè kan kúrò ní İjàyè lọ sí Fìdítì. Așú gba àwọn ọ̣tá Ààrẹ gẹgẹe bí olùgbọ̀wộ. O lẹ̀ dí àpò pọ̀ mọ́ Iba, Iba sì fi Bálógun Ọdẹ́rìnlọ àti İbíkúnlé ráńṣẹ láti lọ ran Așú lọ́wọ́. Gẹgẹ bí àlàyé Johnson (1921), ogun yìi kò rọrùn fún àwọn ọmọ ogun Ìbàdàn torí pé ogun Ààrẹ-Ọnà Kakaǹfò fệrẹ̀ pa gbogbo wọn tán. Kódà bí kì í bá șe pé İbíkúnlé tó jẹ Séríkí ogun İbàdàn nígbà náà bọ́ sọ́wọ́ àwọn ộrẹ rẹ̣ láti İjàyè ni, kò bá bá ogun lọ. Ohun miíràn tó tún ran àwọn ogun İbàdàn lọ́wọ́ ni pé ilẹ șú bá wọn lệnu ogun yií, nígbà tí ilẹ șú, ikú oró tí kò bá pa gbogbo ọmọ ogun İbàdàn rún dáwọ́ dúró. İdí níyì tí wộn fi pe ijà àkộ kọ láàrin İbàdàn àti İjàyè náà ni ogun "Òrugbàmílà". Ogun İbàdàn túnra mú, wọ́n ránșẹ́ sí àwọn jagunjagun Ẹgbá bií S Sódẹkẹ́, Àpati, Ànàbá, Olúfakùn, Șómóyè àti Ògúnbọ̀nà fún ìranlọ́wọ́. Johnson (1921) fi kun pé nígbà tí Aláàfin sọ ọ̣ọ̣ ijà yìi tì ló bá pàșe pé kí wộn gẹgun Șàngó lọ sí ogun náà, èyí fi hàn pé bí ọba ayé kò bá le sọ ọ́ kó parí, ó yẹ kí ọba ọ̀run le parí rẹ̀. Nígbà yìi ni ogun náà tó rọlẹ̣.

Abiộdún (2013) șe àlàyé pé alàgbà Láyíwọlá Adió, ọ̀kan lára àwọn àgbà ilé Kúrunmí ní İjàyè fi yé òun pé, ọba tí Adélú jẹ lệyìn ikú baba rẹ̀ (Àtibà) ló fa ijà ogun İjàyè. Kúrunmí fara mọ́ ogun ju yíyanjú ọ̀ọ̀ náà ní ìtùbí-ìnùbí lọ. İbàdàn tó jẹe ọ̀tá Kúrunmí gbè lẹyìn Adélú, bákan náà ni àwọn ilẹ̀ Yorùbá mìrràn tó tó mệrìnlélógóje níye șe. Báyî́ ni àwọn àpapọ̀ ogun náà dojú ogun Ààrẹ bolẹ̀. Șùgbọ́n kí wọ́n tó rí èyí șe, Ààrẹ Kúrunmí ti fi ìgbà kan mú Bașọ̀run Ògúnmọ́ lá lệrú tó sì jẹe pé eerú ni ó ń fún un lá. İdí nìyí tí wọ́n fi ń ki Ogúnmọ́ lá ní "ọmọ aléérúmákùư". Alàgbà Láyíwọlá Adió fi kún àlàyé rẹ̣ pé gbogbo ìlú İjàyè ni ogun Ogúnmộlá jẹ run gúdúgúdú, ìdí nìyí tí wọ́n fi ń pa á lówe pé, “Ọpẹ İjàyè ló le ròyìn ogun Ògúnmọ́lá” Etí odò Ộsẹ ni ogun ká Kúrunmí mọ́, ibẹ̀ ni ogun sì ti mú un lọ.

Oloyè Adébòyè Onígbíndé3, șàlàyé pé "ète ìlù" ni ogun İbàdàn fi șẹ́gun Kúrunmí létí odò Ộsẹ. Ó ní nígbà tí ogun náà kọjá síso fún àwọn igun méjèjì ni kálukú ti sọ àwọn ọmọ ogun àti àwọn onílù rẹ̀ nù. Onígbíndé tẹ̀ siwájú pé Ògúnmọ́lá ni ó kọ́kọ́ șe àwárí àwọn onílù rẹ̀ lókè odò. Lẹeṣe kan náà ló kó àwọn ọmọ ogun jọ, ó ní kí wọ́n fara pamọ́, ó sì pàșe pé kí àwọn onílù òun ó yíwọ́ ìlù wọn po sí ti Kúrunmí. Gẹegẹ bí Onígbíndé ti șe sọ, Kúrunmí tó wà nísàlẹ odò gbọ ìró ọwọ́ ìlù rẹ̀ bí ó ti ń dún pé:

İjà orogún ò wọ̀

Orogún

İjà orogún ò wọ̀

Orogún

3 Eni tí ó ti fi ìgbà kan jẹe akọnnimọ̀-ọngbà fún àwọn ẹgbẹ́ agbábọọ̣lù àgbà-Ọ̀jẹ̀ ilẹ Nàijíríà (Super Eagle) sọ èyí nibi ayẹyẹ ọdún ìlù (Drum Festival) ti ọdún 2012 ní ọgbà Yunifátitì Ìbàdàn. 
İjà orogún ò wọ̀

Orogún...

Kúrunmí rò pé àwọn ènìyàn òun ti gòkè odò, ó sì fi bẹẹ bọ sí ààrin ộtá. Kò sí ìrànlọ́wọ́ kankan fún un torí pé àárín àwọn ộtá ló bọ́ sí, báyîi ni ó bógun lọ. Gẹgẹ́ bí a șe sọ lókè, a ó rí i pé èdè àyàn (èwì) tí a fi ki oríkì rẹ ni okùnfà pàtàkì tó pilẹ ogun yî́, òhun náà sì tún ni ète pàtàkì tí ọmọ ogun Ògúnmọ́lá lò láti fi șẹgun Kúrunmí, odidi Ààrẹ-Ộnà Kakaǹfò ilẹ̣ Yorùbá. Ohun tí ó jẹ́ kí ète yî́ mú un ni bí ó șe gbáralé èdè àyàn tí ó jẹ́ ohun ìdámọ̀ rẹ̀ lójú ogun. Àșà fífi ohun ìlù dáni mọ̀ tàbí sọ ibi tí a wà yìi wộpọ̀ láarin àwọn jagunjagun ayé àtijọ́.

A le rí "orogún" tí a șe àwítúnwí rẹ̀ yìi gẹgệ bí ègbè èdè àyàn náà. İdí ni pé àwọn onílù tó lu ìlù yií pé méjì, mệta tàbí jù bẹeẹ lọ torí pé wộn jẹe onílù ogun nínú èyí tí a ti gbọ́ dọ rí olómele àti alùyá ilù. Ohun tí "İjà orogún ò wộ" ń tọ́ka sí ni pé, ìjà orogún máa ń le, ó sì kún fún oríșiírísịi ète. Yorùbá a tilẹ máa pa á lówe pé, "Ríro ló ro ni a fi pè é ní orogún, kíkan lo kan la fi pè é ní ọbàkan”. Bí èyí bá rí bẹẹe, ó yẹ kí á le șe ìbéèrè pé șél Kúrunmí tó jẹe olórí ogun ilẹ Yorùbá kò mọ tẹ́lẹ pé wọ́n le dẹ irúfẹ́ okùn bẹẹ fún òun ni? İdáhùn sí èyí ni pé "A kì í gbộn bí ẹni tó ń sọo ni", àti pé "Bí sệrià bá fệ láti dá àjànnàkú, fọ́nrán òwú kan a máa gbé e dè”. Kì í șe pé a fẹ́ láti fi Kúrunmí hàn gẹgẹe ẹni Ibi, ohun tí a fẹ́ tộka sí ni pé kò sí ẹni tí ète ọ̀tá kò le mú.

\section{5 Àmúlò Òòșà-Èrò (òkúta) Láti Fi Șẹgun Fúlàní Adigunjalè Ní Igbó-Ọrà Látijọ́}

Olóyè Wahabi Láwànì Àyísá ${ }^{4}$, șàlàyé pé lệyìn ogun İdàhộmì, tí àwọn ènìyàn ìlú Igbó-Ọà rò pé ogun ti tán ni ògbólógbòó fúlàní adigunjalè kan tún bẹ̀rẹ sí níi yọ İgbó-Ọrà lệnu. Fúlàní yìi a máa ti agbègbè ìgbèríko Abẹèkúta wá. Gbogbo agbára ni àwọn jagunjagun àsìkò náà sà láti kápá olè yií șùgbộn wọn kò rí i gbé ṣe. Ó șe ní ojộ kan, àwọn ìlú gbọ́ pé olè náa tún ń bọ̀ wá, wộn sì ti múra ogbộn tí wộn yóò lò fi bá a jagun. Bí ó ti dé tó ń bá àwọn jagunjagun yî́ jà lộwọ́ bí ti í máá șe, wộn șá a lọgbẹe kò ràn án, wọ́n ta á lộfà kò rí i gbé șe, wọ́n dìgbò lù ú kò balẹ bẹeẹ sì ni òògùn ò ràn án. Àwọn jagujagun yì́ ti fẹ́ máa sá lọ tí kò sì sệni tó rántí ète mìràn tí wọ́n pa kalẹ dè é mọ́. Olóyè Wahabi Àyísá tẹ̀ síwájú pé șàdédé ni ẹ̀nìkan nínú wọ́n bẹ̀rẹ̀ sí níí kọrin, tí àwọn yòókù sì ń bá a gbè é pé:

Lílé: Enikan kì í róògùn òòșà-èrò șe

Ègbè: Ò̀òsà-èrò

4 Ìkộlàbà ilú Igbó-Ọà tó gbésẹ̀ ló șọ èyí lásìkò tí mò ń șe akitiyàn láti kó àwọn ìtàn tó jọni lójú nípa ìlú Igbó-Ọrà jọ. 
Lílé: Enìkan kì í róògùn òòșà-èrò șe

Ègbè: Ò̀șà-èrò...

Lọ́gán tí èyí șẹlẹ̣, àwọn jagunjagun náà rántí ète tí wọ́n ti pa kalẹ̣, kálukú sì bẹ̀rẹ̀ sí níi sọ àwọn òketè òkúta tí wọ́n ti pèsè kalẹ bá ọoọṣà yií. Òtítọ́ ni adigunjalè yî́ ní òògùn oríșiíríșií șùgbộn kò múra tòkúta lộwọ́. Kò sì lérò pé wộn le ja irúfẹ́ ijà ijàǹbá bẹẹe. Bí wọ́n ṣe fi òkúta tí ọ̀ kọin náà fi orin rẹ̀ rán wọn létí șẹgun nìý́.

A fẹ́ ká kíyè sí i wí pé ẹni tó rán wộn letí ète yìi kò pe ète náà ní orúkọ tí gbogbo èèyàn mọ ộn sí, dípò bẹẹ̣, ó pè é ni orúkọ tó jẹ pé bí èniyàn kò bá gbọ́ èdè Yorùbá dunjú, kò le mọ itumọ rẹ̀, șé Fúlàní sì kúkú ni ẹni tí wọn ń bá jà, kò gbọ́ èdè Yorùbá púpọ. Ohun tí ộkọin șe àmúlò níbí ni lílo èdè àdàpè láti fi da nǹkan rú mọ́ ọ̣tá lójú. A tún le pe àmúlò "òòsà èrò" níbí yìi ní ẹnà, tí ọmọdé tàbí àjèji/aláìgbédè, tí kò mọ àșà àti èdè àwùjọ dunjú kò le gbọ́. Ká ní òkúta ni akéwì pè é ni, bóyá kò bá funra, kí ó sì túnra mú tàbí kó kúkú máa sálọ. Báyií ni akéwì náà șe șe olùgbàlà ilú Igbo-Ọà nípa lílo ète ewì láti fi rán wọn létí ọ̀nà ẹ̀ bùrú tí wộn fệ báyọ sí ogun olè tó ń jà wộn náà.

A tilẹ tún gbọ́ pé lọgán tí ọwọ́ ba ọkùnrin yî́ ni ère tí ìyàwọ rẹ̀ máa ń fún lộyàn kí ó ba à le șẹ́gun kò gba ọmú mộ. Șé ó kúkú máa ń mọ ilú tí ọkọ rẹ̀ bá ń lọ jà lólè, ó forí lé ibẹ̀, ó sì ń pariwo pé
Àwòrán ò mọ̀mọ́
Bàbá gbàmí
Àwòrán ò mọ̀mọ́
İyá gbàmí
Àwòrán ò mọ̀mọ́
Ará ilé gbà mí
Àwòrán ò mọ̀mọ́
Èrò ọ̀nà gbà mí
Àwòrán ò mọ̀mọ́ 5

Ohun tí ó ń sọ ni pé àwòrán (ère) agbára ọkọ òun kò gba ọyàn mọ́, kí wọ́n jọ̀wọ́ má pa ọkọ òun. Ėre ni ó pè ní "àwòrán", "kò mu ọmú” sì ní ó fẹ́ wí tí ó fi sọ pé "kò mọmoọ". Ėyí túnbọ fi hàn pé aláìgbédè ni tọkọtaya ọlọṣà náà, àìgbédè Yorùbá dáradára wọn sì kún inú ohun tó șekú pa wọ́n. Báyií ni wọ́n șe irú ìdájọ́ tí wọ́n ṣe fún ọkọ rẹ̀ fún un; wọ́n pa á pẹ̀lú òkúta.

5 Orin yiî jẹe èyí tí a gbọ́ lệnu Olóyè Wahabi Àyísá bákan náà. 


\section{6 İja Ėsìn Láàárin Àwọn Ọmọ İșòrò àti Àlùfáà Kamar-ud-deen ní İlú İgbó-Ọà Lọ́dún 1993}

İtàn ajẹmógun miíràn tó tún fìdí èrò pé ewì jẹ ète ogun jíjà múlẹ ni ìja ẹsìn lááárin àwọn ọmọ ìsònò àti àlùfáà Kamar-ud-deen ní ìlú İgbó-Ọrà ní oṣù kejì, ọdún 1993. Ó șojú mi kòró ni ị̀ẹẹẹ tí ń ó sọ yìi. Ọdún orò ni ìlú Igbo-Ọà ní oṣù kejilá, ọdún 1993 wáyé bí ogun ni. Lọ́wọ́ òwúrọ kùtùkùtù ọjọ àháṣúlệ/ ìséde/ìkìje orò tí àwọn eégúnrò mẹrin ìú Igbó-Ọrà máa ń jádé, àwọn eégúnrò náà ni Lájọrun, Láșogbà, Lágayè àti Ògbojà, òkìkí șàdéédé kàn pé alùfáà Kamar-ud-deen ti kó àwọn obìnrin dé ọjà Igbo-Ọà. Gbogbo ènìyàn, yàtọ sáwọn obìnrin ló lọ wòran ìṣẹ lẹ náà. Bí àlùfáà yiî́ șe dé, iwájú mọsạ́láșí ọjà ló duró sí àti àwọn ẹlẹ́hàa rẹ̀. Wộn ń kọrin àsàláátù lóríșiíríșîí, wộn sì ń lu ìlù bẹ̀nẹ̣ àsàlátù sí i. Gbogbo wọn ń jó. Kó pẹ sí ìgbà yîi ni Lájọrun ń ti igbórò rẹ̀ bọ̀. Ó ti wà nínú eégúnrò, șe òkìkí ti kàn bá a tệlẹ̣, ó bá wọn lótiítộ, ó bá bẹ̀rẹ̀ sí níi pa itú méjeméje fún wọn. Sí ìyàlẹnu gbogbo ènìyàn, ọ̀kankan nínú àwọn ọ̀pọ̀lọpọ̀ obinrin wọ̀nyí kò kú. Lẹ́nu èyí ni gbogbo àwọn orò yòókù bá wọn, gbogbo wọn ló pa itú șùgbọn bákan náà lọ̀rọ̀ rí. Àwọn ènìyàn tó wà níbẹ rí èyí sí ìyàlẹ̀nu, kálukú sì káwọ́ gbera. Ká ni àkókò yî́ ni àlùfáà yií bá kó àwọn ènìàn rẹ̀ sọ́kọ̣ tó forí lé ọnà Abẹè̀úta tó bá wá kò bá yẹ ệ, șùgbọ́n kò șe bẹeẹe. Àwọn ọmọ ìlú ka èyí sí ìwộsí ńlá àti ìgbésẹ láti pa orò ọdún run. Lọgán ni orin kan sọ láàárin àwọn òǹòran pé:

Lílé: Bóògùn ò ràn wọ́n ò

E kógi bò wọ́n o

Bóògùn ò ràn wọ́n

E kógi bò wọ́n o

Bó bá șe póbinrin ni ó borò jẹ́ o

Ègbè: Bóògùn ò ràn wọ́n

E kógi bò wọ́n o

Lílé: Bó bá șe póbinrin ni ó borò jẹ́ o

Ėgbè: Bóògùn ò ràn wọ́n

E kógi bò wọ́n o

Lẹesẹ kan náà ni àwọn ènìyàn bẹerẹ sí níí ju òkò, igi, páléke, eegun ẹran àti bẹẹ bẹẹ lọ lu àwọn ijọ wọ́nyí. Lójú ẹsẹ̀ ni ẹ̀jẹ ti bo àwọn ẹlệhàa náà, wọ́n ṣe àwọn ọkùnrin wọn bọṣẹ șe ń șojú, wọ́n ba gíláàsì àwọn ọọ̣ wọn jệ, wộn sì șetán láti pa gbogbo wọn. Àwọn ọlộpàá tó wà ni ibi ị̀ẹ̣lẹ̣ yìi kò gba èyí láyè, wộn bẹ̀rẹ sí níi yin ìbọn tajútajú, wọ́n sì le gbogbo èniyàn kúrò láti fi dóòlà ẹ̀mí àwọn ènìyàn yìí.

Bí a bá wo orin yií, kókó ohun tí ọ̀ kọrin náà fẹ́ kí àwọn ènìyàn tó fẹ láti gbèjà ìú wọn șe ni ó kọ́kộ șe àwítúnwí rẹ̣ ní ẹẹmejì bí ó șe sọ pé "Bóògùn ò ràn wộn ò; E kógi bòwọ́n o" ní kí ó șẹ̦̣̣e tó wá sọ pé "Bó bá șe póbinrin ni 
ó borò jẹ́ o". Láti fi hàn pé ohun tí ọ̀kọrin náà sọ yé àwọn, ohun tó fệ kí wộn șe "Bóògùn ò ràn wọ́n; Ẹ kógi bò wọ́n o" tó sọ ní ẹ̣ẹmejì yií náà ni àwọn náà fi gbe orin yìi. Ohun tí ó șẹlẹ níbí ni pé ọ̀ kọrin mọ̀-ọ́nmộ yí ìhun gbólóhùn orin yiî́ padà torí kí ó le tẹnu mọ́ "Ẹ kógi bò wọ́n o" tí ó fẹ́ kí wọ́n șe ni. Bí ó șe yẹ kí ihun orin yì́ jẹ́ ni:

Lílé: Bó bá șe póbinrin ni ó borò jẹ́ o

Bóògùn ò ràn wọ́n

E kógi bò wọ́n o

Ègbè: Bó bá șe póbinrin ni ó borò jẹ́ o

Bóògùn ò ràn wọ́n

E kógi bò wọ́n $o$

Orin náà á wá jẹ àjùmọ̀ kọ tàbí kí ó jẹ pé gbólóhùn tí ọ̣ kọrin fi lé orin náà ni àwọn elégbè fi gbè é. Bí èyí bá rí bẹẹe, a jẹ pé obìnrin tí a kộ kọ́ dárúkọ ni ó șe kókó jùlọ nínú gbólóhùn orin náà. Șùgbộn torí pé ète fífi igi bá ọtá jà ló șe kókó sí ọ̀ kọrin, ìdí nìyí tó fi jẹ pé gbólóhùn "Bóògùn ò ràn wọ́n; E kógi bò wọ́n" ló kọ́ kọ́ sọ.

Ohun tí a tún fẹ́ kí á kíyè sí nínú ìșẹlẹ̣ yî́ ni pé, bí kò bá șe ọgbọ́n àti orin ewì tí àwọn kan fi ta àwọn ọmọ ìsòorò àti àwọn ènìyàn yòókù tó wà ní ibi ị̣̀ẹlẹ̣ náà jí ni, ó șe é șe kí àlùfáà Kamar-ud-deen ti gbé orí Lájợun lọ. Ohun tí a rí tí a fi sọ báyìi ni pé, níșe ni Lájọ̀run, tó kộ kọ́ dé ibi ìṣẹẹ̣ náà, fúnra rẹ̀ ti ṣọ fún àwọn onílù àgẹrẹ-orò rẹ pè kí wọ́n pàlù tó sì jẹ pé bẹnhẹe àwọn ìjọ yî́ ló ń jó bí òkòtó. Torí náà bí kò bá șe orin (ewì) tí ó ta àwọn ènìyàn jí láti dá irú ogbọ́n yìi àlùfáà náà kì bá șẹ́gun tí kò bá sì sọ ara rẹ̀ di pàtàkì.

\section{0 Àgbálọgbábọ̀}

Kókó ohun tí a fìdí rẹ̀ múlẹ níbí ni pé ọ̀kan lára àwọn ète tí Yorùbá máa ń lò láti fi jagun ni ewì jệ. A șọ àwọn ìtàn ogun nínú èyí tí a ti șe àmúlò ewì gẹgẹe bí ète ogun. A sọ irúfẹ́ ewì tí a șe àmúlò lójú ogún, bí a ti șe lò wộn àti ìdí pàtàkì tí ète ewì náà fi mú àwọn ọ̀tá tí a dẹ wộn fún. İwádí yìi fi hàn pé a le lo ewì gẹgẹe bí ète ìdẹ́rùbani, ìdájàsílẹ, ìránnilétí, itannijẹ, ẹ bẹ àti àyẹesí lójú ogun. Àwọn ìlò ewì wọ̀nyí ni ètè pàtàkí tí ó mú àwọn tí ó lò wọ́n șẹ́gun ọ̣tá. A fi hàn nínú àlàyé wa pé bí a ti șe le fi ewì dógun sílẹ gẹegẹ bí àwọn onílù Ibá șe șe nínú ogun İjàyè, tí a lò ó fún ìsẹggun gẹgẹe bí Ògúnmọ́lá șe fi mú Kúrunmí náà ni a le lò ó gẹgé bí ọ̀nà ìyanjú aáwọ̀. Ėyí ni àpẹere Aṣawo àti Eléńre tí a șe. Ohun tí èyí ń sọ nípa ewì ni pé, "Ilẹ̀ tó bá șojú ẹni șú òòkùn rẹ̀ kì í șòro rìn" àti pé "Ė̀nyyàn tó màtidé olú-ǹnàgó ni yóó mọ àtilọ rẹ̣". İwúlò méèjì yìi fi ewì hàn gẹgẹ bí idà olójúméjì. A fẹ́ kí àwọn olórí àwùjọ, àwọn ọba, ìjọba àti àwọn olórí ẹsìn gbogbo máà gbìyànjú láti máa șe àmúlò ète ewì lộnà tó báwùjọ 
òde-oní mu fún yíyanjú àwọn aáwọ̀ tó máa ń șẹlẹ̀ láwùjọ dípò lílo agbára/ipá tí wọ́n máa ń lò lọ́pọ̀ ìgbà. Bí a bá șe èyí, yóò fi àwùjọ wa hàn gẹgẹé bí àwùjọ tó ń șe àmúlò àwọn ohun ogún ìbí rẹ̀ láti yanjú ị̀òoro rẹ̀. Yóò sì mú kí á le máa șe ìwádií nípa bí a șe le lo àwọn ohun abẹ́lé wa fún ìdàgbàsókè àwùjọ wa.

\section{İwé İtọ́kasí}

Abiọ́dún, T., 2013. "Kúrunmí: Valiant Warrior”, The Nation,thenationonline. ng.net>kunrunmi-valiiant-warrior.

Adébọ̀wálé, O., Olúmúyìwá, T. àti Așíwájú, J. 2018. “Àyẹ̀wò Ogun Ẹnu Nínú Àșàyàn Fíìmù Àgbéléwò Yorùbá”, nínú Yorùbá: Journal of Yorùbá Studies Association of Nigeria, vol. 9 no. 1, o.i. 1-23.

Adéoyè, C. L., 1979. Àsà Àti İṣe Yorùbá. Ìbàdàn: Oxford University Press.

Ahlul Bayt Digital Islamic Library Project, 2017. "Battle: The Life of Muhammad, The Prophet”, Ahlul Bayt Digital Islamic Library Project, www. al-islam.org

Arógundádé, N.O. 2017. "War and Diplomacy”, nínú Customs of the Yorùbá, Olóòtú, Falọlá àti Akíntúndé Akínyẹmí, o.i. 647-657.

Awẹ́, B. 1975. "Notes on Oríkì and Warfare in Yorùbáland" nínú Yorùbá Oral Poetry, Abímbọ́lá Wándé, Ẹka-ẹ̀kọ Ėdè Ilẹ̀ Adúláwọ̀ àti Lítíréṣộ, Yunifásitì Ifẹ̀, o.i. 267-292.

Cleretian Publication, 2003. The Holy Bible King James Version. China: Franchrix Publisher.

Dáramọ́lá àti Jẹ́jệ, 1975. Àwọn Àṣà Àti Òrị̣à Ilẹ Yorùbá. Ìbàdàn: OnibọnÒjé Press.

Faṣehun, M.A. 2018. “Ipa Tí Ogun Ẹnu ń Kó Nínú Àwùjọ”, nínú Yorùbá: Journal of Yorùbá Studies Association of Nigeria, vol. 9 no. 1, o.i. 76-103.

Finnegan, R. 2012. Oral Literature in Africa. United Kingdom: Open Book Publishers.

Fitzgerald, 2017. Ancient Greece War, Finer Timer (Excellent in Content). www.thefinertime.com.bloomsbury.com

Gates, D. 2001. Warfare in the Nineteenth Century. New York: Palgrave.

Johnson, O. S. 1921. The History of the Yorùbá: from the Earliest Time to the Beginning of the British Protectorate. London: Routledge and Kegan.

Ògúndèjì, P.A., 1991. Introduction to Yorùbá Oral Literature (İfáárà Sí Litíréṣo Yorùbá). İbàdàn: İbàdàn Distance Learnimg Centre.

Odúnjọ, J.F. 1971. Aláwiíyé: İwé Kẹfà. İkẹjà: Longman Nigeria PLC.

Ọwọ́adé, S.C. 2018. "Ipa Pàtàkì tí Orin ń Kó Nínú Ètò Ogun Jíjà Nílẹ Yorùbá", nínú Yorùbá: Journal of Yorùbá Studies Association of Nigeria, vol. 9 no. 1, o.i. $131-156$ 
Pomeroy, et'al 2004. A Brief History of Ancient Greece: Politics, Society and Culture. New York: Oxford University Press.

Ramakrishna, 2015. "The Truth about Alexander", hinduwebsite.com

Riffatarre, M. 1978. Semiotics of Poetry. Bloomington: Indiana University.

Shiffered, S.J., 2005. "A List of Remarkable Bible Battles", godsbreath.net

Sotunsa, Mobolanle E., 2005. Features of Talking Drum Poetry, Ișé-İwádií fún Gbígba Oyè Ph.D ní Ẹka-Ẹ kọ́ Èdè Gẹeẹsì, Yunifásì Ibadan, Nigeria.

Townshend, C. 2000. The Oxford History of Modern War. New York: Oxford University Press.

Yémitàn àti Ogundélé, 1970. Ojú Oșùpá: Apá Keji. Ìbàdàn: Oxford University Press.

\section{Àwọn Abẹ́nà-ìmọ tí a Șàmúlò ọ̀rọ Ẹnu Wọn}

Fágbénlé, Awólộwọ̀ 2021. "Ìfọ̀rọ̀wánilệnúwò Nípa Aṣawo àti Eléńre" tó jẹ́ ọmọ ìlú Ayétẹ̀, İpínlẹ OÒyọ́, Nigeria.

Lawani, Wahabi Àyísá, 2004. "İtàn Fúlàní Ollọsạà tó ń Yọ Igbó-Orà Lẹ́nu”, Agbo-Ilé Àkànní-Àwíșẹ, Òkè-Odò, Igbó-Ọra, Nigeria.

Onígbíndé, Adébóyè, 2012. "Ọ̀ọ̀ Àpilẹ̀sọ Rẹ̀ Nípa Ìlù Níbi Ọdun Ìlú", tó Wáyé Nínú Ọgbà Yunifásítì İbàdàn, Nigeria. 